\title{
THE DEVELOPMENT OF THE GAMETOPHYTES AND FERTILIZATION IN JUNIPERUS COMMUNIS AND JUNIPERUS VIRGINIANA
}

Alice M. Otthey

(WITH PLATES I-IV)

\section{INTRODUCTION AND METHODS}

The present paper is based upon a study of Juniperus communis and of Juniperus virginiana. J. communis was worked out more in detail, and throughout the following description it is the species referred to unless otherwise stated. Since this study was begun, two papers, SLUdSky (22) and NorÉn (20), based on a study of J. communis, have appeared. In the main NorÉN's observations have been confirmed by the present study. He gave a very complete history of the literature relating to Juniperus and it will not be necessary to repeat it here.

The pistillate and staminate cones of $J$. communis were collected about one and a half miles southeast of Wellesley, Mass., those of $J$. virginiana from the campus of Wellesley College and near-by places. The collection of the material began the second week in March, I905, and continued until the latter part of June of the same year. Fresh material was gathered once a week from March 13 through the first week in May; from May 8 until June 26 collections were made twice a week. The material was kept in water and put up approximately every other day. Pistillate cones of $J$. communis for I903, I904, and $\mathrm{I}_{905}$, and of $J$. virginiana for $\mathrm{I}_{905} \mathrm{5}$ were collected; the staminate cones were put up until the shedding of the pollen, which in I905 was on May 9 for J. virginiana and May I I for J.communis. The fixing agent used was Flemming's chromacetosmic solution and the stain gentian violet and orange $\mathrm{G}$.

Besides the slides prepared from this material I have had the privilege of studying one hundred slides which were prepared by Miss FERGUSON in the spring of I903. These were of great value in giving the approximate dates at which to look for certain desirable stages, 3. 7

[Botanical Gazette, vol. 48 
as well as in showing the variation in time of the occurrence of certain phenomena due to varying climatic conditions of different seasons. It is interesting to note that the different stages of development as worked out by NoRÉn from material collected in Sweden were, in general, from three to four weeks later than corresponding stages in the material collected at Wellesley.

\section{MALE GAMETOPHYTE}

Both $J$. communis and J. virginiana are dioecious, occasionally monoecious. RENNER (2I) reported the presence of hermaphrodite flowers in J. communis. I searched for similar flowers during the period of collection, but was unable to find any. The microsporangia were fully developed and the microspore mother cells were already present in $J$. virginiana on March 28, but in $J$. communis the microsporangia were not differentiated until April I3. The sporophylls are cyclic in arrangement and are disposed in whorls of three, with the microsporangia on the under side next to the axis of the cone (fig. I). On April 25 the cells of the archesporial tissue were undergoing their last division before the formation of the microspore mother cells. Following this division, each microsporangium consists of a central mass of polygonal microspore mother cells; surrounding these is a single layer of tapetal cells, rich in protoplasm and containing large nuclei, and a wall of two layers of cells ( fig. 2), as has been described by other writers. The cells of the outer or superficial layer of the wall are large and tabular. They contain considerable resin, which causes them to stain diffusely.

Very soon after the differentiation of the microspore mother cells the heterotypic division begins. LOPRIORE (I8) reported that the microspore mother cells of Araucaria Bidwillii also undergo a very short period of rest before this division is entered upon. As soon as the walls are formed about each microspore, the mother wall breaks down, setting the spores free in the sporangium.

The microspores increased in size and were shed May II. The mature pollen grains of Juniperus do not differ as to content from the microspores. In the spring of 1903 pollination took place in $J$. virginiana on April 22, but in the spring of 1905 not until May 9. There is, then, a variation, due to seasonal or climatic conditions, of 
more than two weeks in the time at which the pollen may be shed. The microspore in $J$. communis and in $J$. virginiana undergoes no division in the anther, and so far as I have been able to determine no prothallial cells are ever formed in them. This agrees with the condition found in J. communis (BELAJEFF 2, Norén 20), in Biota and Cupressus (Strasburger 27), and in Taxus baccata, J. sphaerica, and $J$. chinensis (COKER 6). In Thuja (LAND I4), Libocedrus and Chamaecyparis (LAwson I7), a division takes place while the pollen grains are still in the anther and gives rise to the tube and antheridial cells, but in these also no prothallial cells are ever formed.

The mature pollen grain has two walls, a deeply staining outer one and a faintly staining inner one (fig. 3). The outer wall of the pollen grains appears slightly roughened in many instances. When pollination takes place, the one-celled pollen grain comes to rest on the nucellar cap, the cells of which immediately lose their nuclei and become more or less disintegrated and collapsed, forming a depression in the top of the nucellus (fig. 6; Norén, pl. I, fig. 5). Fifteen days after pollination the microspore divided to form the tube and the antheridial cells. The antheridial cell is the smaller of the two and remains always at one end of the pollen grain, while the tube cell is larger, possesses less dense cytoplasm, and its nucleus occupies the center of the pollen grain. Many starch grains are present at this time in the tube cell. The nucleus is large, with a loose chromatic network, and contains one nucleolus (fig. 5). As described by NoRÉN (20), immediately after the division to form the antheridial and the tube cells, the pollen grain germinates, and the tube pushes its way down into the tissue of the nucellus, but by June 26 it has reached only a short distance. The tube nucleus migrates into the tube, but does not reach the end of it until the following spring; whereas in $J$. virginiana the tube nucleus passes at once into the tip of the tube ( f g g. 8), and fertilization takes place in the early summer of the same year.

Soon after germination in $J$. communis, the exine is shed in the pollen chamber and remains there, a dark-blue shell, as has been described for Taxodium by CokeR (5). In many cases the pollen grain end of the tube is raised up above the nucellar tip into the pollen chamber, giving a peculiar appearance. This may be caused by the 
germination of the pollen grain before it reaches the nucellus, or it may be that the pollen tube finds difficulty in piercing the tissue of the nucellar cap, and in the effort to do so the pollen grain end is pushed up into the pollen chamber. From the appearance of the pollen tube lying in a horizontal plane on the nucellar cap before the tip enters the nucellus, it seems quite probable that the latter explanation is the more suitable one.

The following spring the antheridial cell divides to form two nearly similar cells, the stalk and the generative cells. The division was not observed, but on May 8 the two cells had been formed and were seen in the pollen grain portion of the male gametophyte (figs. 9, Io). NoRÉn gives no figure illustrating this stage and speaks only of a stalk nucleus. The two cells soon move down the tube. At first they are very similar in appearance, but in a short time the generative cell is easily distinguished by its larger nucleus, and by the fact that it retains its own cytoplasm; while that of the stalk cell is not distinguishable after passing into the tube, as in Thuja (LAND I4) (figs. 9-12). Not until after the stalk nucleus has passed the generative cell does the nucleus of the latter appear larger than either the stalk or the tube nucleus (fig. I2). At this time the generative cell increases rapidly in size, and its nucleus becomes several times larger than either of the other two nuclei. The difference in size of these nuclei is more marked in J. communis (fig. I3) than in J. virginiana (figs. II, I2). Neither in J. communis nor in J. virginiana is it possible, as stated above, to detect the cytoplasm of the stalk cell in the pollen tube. That the entire cell loses its connection with the wall of the pollen grain and starts into the tube is clearly shown in fig. Io. But very early in its downward course its cytoplasm fuses with the general cytoplasm of the tube and can no longer be distinguished from it.

The end of the tube with its cytoplasmic contents advances toward the female prothallium and spreads over the upper end of the archegonial complex (fig. 27). The generative cell takes its position in the center of the tube near the tip, and strands of protoplasm extend from it to the lateral walls of the pollen tube and below to the tip. The stalk and the tube nuclei, which are usually of the same size and can no longer be distinguished from each other, are side by side below 
the generative cell. This corresponds with the condition at this time in Thuja as described by LAND (I4). As noted by NorÉn, no starch appears in the pollen tube at this time. Previous to the division of the generative cell its cytoplasm becomes decidedly alveolar in appearance (fig. I3), suggesting the appearance of this cell in Zamia (WEBER 29), Cycas (Ikeno 9), and Sequoia (Lawson I5). Norén does not speak of this appearance, but describes the cytoplasm as coarse grained and containing a large amount of finely divided starch which might easily escape observation. I was unable to find any signs of starch in this cell at any time in its history.

Just before fertilization the generative cell divides and forms two cells equal in size ( fig. 27), as shown and described by Norén. This agrees with Biota (Strasburger 27), Thuja (LAND I4), Taxodium (Coker 5), and Cryptomeria and Sequoia (Lawson r 5, r6). When mature the two sperm cells in Juniperus are hemispherical in shape and lie with their flat sides face to face, but not in contact, as described by NorÉn, and in Thuja by LAND (I4). The division of the generative cell occurs normally in Juniperus after the tube has reached the neck of the archegonium, but in one instance two similar nearly spherical cells which resembled generative cells appeared in the pollen tube when it was about half-way through the nucellus.

It would seem that the two sperm cells may both be capable of functioning, as LAND (I4) thinks is the case in Thuja. They are equal in size, the archegonia are borne in complexes, and the tip of the pollen tube is pressed against the neck cells of several archegonia, thus making it possible for the sperm cells from one tube to enter different archegonia. Two or three pollen tubes may reach the same archegonial complex, and there is very little branching of the tubes in their way through the nucellus.

\section{FEMALE GAMETOPHYTE}

On March 28 the ovuliferous cones had appeared, but there were no indications of ovules. The first stages in their development were observed May I. There are, as a rule, three ovules borne in the same horizontal plane at the apex of the cone. The integument arises as a little swelling at the base of the nucellus, and by May 8 it had passed beyond the top of the nucellus. But one integument is present, and 
it is free to the base of the nucellus (fig. I4; Norén, pl. I, fig. 5). The arms of the integument are composed of three to five layers of cells. The micropyle is wide and deep, and no depressed pollen chamber is present until after pollination. The nucellar cap is composed of large clear cells, which in the upper layer project up, thus giving a jagged or irregular outline to the top of the cap. The cells beneath these are smaller, more nearly isodiametric, are arranged concentrically, and contain large darkly staining nuclei (fig. I 4). NorÉn does not find this concentric arrangement until after pollination.

At the time of pollination, a drop of clear liquid resembling a crystal bead is deposited on the top of each of the three ovules. It is probable that the pollen falls on this drop and is drawn down into the micropyle by the drying of the liquid, as has been described for other gymnosperms. The closing of the micropyle is brought about by the rapid elongation of the inner row of cells of the arms of the integument. Occasionally the two arms meet in a straight line (fig. I5), as in Pinus (FERGuson 7). More often, however, the arms dovetail together (fig. 16.), also figured by NorÉn. By this method the micropyle is even more securely closed. Following the elongation of the cells cross-walls are laid down, cutting the lengthened cells into smaller ones. Coker (5) describes a similar elongation of the inner row of cells in Taxodium, while Miss Ferguson (7) finds it in the middle row of cells in Pinus, and Lawson (I6) states that in Cryptomeria japonica the subepidermal and the epidermal rows both elongate. NoRÉn reports that the closing of the micropyle in J. communis has recently been described by KUBART (I 3 ), but I have not seen this paper.

Soon, in the lower part of the nucellus, several faintly staining cells appear, the so-called spongy tissue of STRASBurger. It is one of these cells that, in the following spring, is differentiated into the macrospore mother cell. It is very probable that it was the presence of this spongy tissue which led Hofmeister (8) to the opinion that the macrospore mother cell developed in early summer. Norén says that usually the macrospore mother cell could be distinguished by the beginning of July, but that occasionally two or four cells enlarge, and then it is impossible to tell which is the macrospore mother cell until the follow- 
ing spring. In my material, the macrospore mother cell in J. communis was never differentiated until the spring following pollination.

Soon after pollination, May i I for $J$. communis, the ovules cease to grow and remain practically the same size until the following spring (figs. I5, I6). In J. virginiana, however, the ovules continue to grow, the macrospore mother cell is differentiated, the female gametophyte is formed, and fertilization takes place in the latter part of June or the first of July of the same year in which the ovules were pollinated. SLudsky (22) described fertilization in J. communis as taking place in the same year as pollination. Both NorÉN's studies and the present investigation show that over a year elapses between pollination and fertilization in J. communis. It seems highly improbable that SLUDSKy could make a mistake in the age of the cones with which he was working, as suggested by Chamberlain (3) in a recent review in the Botanical Gazette. Since the present study shows conclusively that the time elapsing between pollination and fertilization in different species of Juniperus may vary by nearly a whole year it seems far more probable that SLUDSky was working with some other species than $J$. communis, and that in the species with which he worked fertilization does take place in the summer following pollination, as is the case in J. virginiana.

In $J$. communis growth began again in the early part of April. The macrospore mother cell appeared April I4 in the basal portion of the nucellus, and three days later the cell divided. In the prophase of the first division the cytoplasm is vacuolate except at one point, a short distance below the nucleus, where it is dense and stains more deeply (fig. I8), as noted by NoRÉN. A similar densely staining mass of cytoplasm is present in all stages of division in the macrospore mother cell. No connection between this body and the division figures could be traced. Coker $(\mathbf{5}, \mathbf{6})$ observed a similar condensation in Taxodium and in Thuja, but was unable to determine its significance. The presence of synapsis, the character of the spirem after synapsis, and the shape of the chromosomes indicate that this is a heterotypic division. In one slide studied there seemed to be evidence of a fourcelled axial row, but from the material examined it was impossible to determine definitely whether the axial row consists of three or four cells. NorÉn states that there are three cells. 
The basal cell of the axial row develops into the embryo sac. Fig. 22 shows a two-celled embryo sac, with the disintegrating remains of the other cells of the axial row above it. Immediately after the first division of the macrospore nucleus, the two daughter nuclei take up a position at opposite poles of the embryo sac, and the cytoplasm becomes more vacuolate. The cells surrounding the developing prothallium are large, usually binucleate, and suggest a tapetum, as described for Taxodium by Coker (5). The nuclei of the prothallium divide simultaneously and form an ever-increasing ring of free cells ( fig. 23). A layer of spongy tissue surrounds this ring and separates it from the other cells of the nucellus. By May 30 cell walls are laid down between the free nuclei, beginning at the periphery and extending toward the center. Contrary to Sokolowa's (23) generalization for gymnosperms, and NoRÉN's observations for $J$. communis, cross-walls are formed before the central vacuole has entirely disappeared.

In the upper end of the prothallium a few cells do not divide by cross-walls, but remain long and narrow. These are the fundaments of the archegonia. By the latter part of May or first of June, the nuclei in these cells divide and give rise to the mother cell of the neck cells and to the central cell of the archegonium (figs. 24, 25). The central cell remains undivided until just before fertilization. Its nucleus is in the upper half of the archegonium, and below it is a large cylindrical vacuole. The cytoplasm stains faintly, and the nucleus contains several nucleoli. As a result of the division of the central cell, there arise the egg cell and the ventral canal nucleus. As observed by Norén (20) and SLudsky (22) no distinct ventral canal cell is ever formed. During the division the cytoplasm stains very deeply and presents a most peculiar appearance. Scattered throughout the entire cytoplasm are many bodies with deeply staining centers which are the so-called protein vacuoles. Three centers of radiations are present in the cytoplasm at this time, two below the large vacuole and one above it. The radiations appear to have no connection with the division of the central cell, but they are never seen so clearly at any other time as during this mitosis. Somewhat similar radiations are described by Coker (5) for Taxodium. NoréN $(\mathbf{I 9}, \mathbf{2 0})$ and Studsky (22) figure and describe them for Juniperus, 
but cannot explain them. Fig. 26 shows these radiations in an early prophase of the division of the central cell.

After the ventral canal nucleus is cut off, it moves to the micropylar end of the cytoplasm and usually disorganizes before the pollen tube bursts. Fig. 28 shows an unusually large ventral canal nucleus. The egg nucleus increases in size and moves slowly toward the central vacuole, taking up a position just above it. It usually possesses a beautiful chromatin network and a large nucleolus or several smaller nucleoli. At this time both the radiations and the protein vacuoles disappear, and many darkly staining specks appear in the egg cytoplasm (fig. 27). Contrary to what I have observed and SLudsky (22) has reported, NoRÉN (20) says that these centers of radiations, so noticeable at the time of the division of the central cell, increase in size during the maturation of the egg. There is no evidence whatsoever of this in the material which formed the basis of the present study.

The archegonia form a complex which is surrounded by a layer of sheath cells. These are small and filled with deeply staining protoplasm. Hofmeister (8) says that Juniperus frequently has archegonia in abnormal positions and Norén has made the same observation. The only case of archegonia in abnormal positions that was observed, is shown in fig. 36. Here the archegonium is outside of the layer of sheath cells, but in other respects it appears normal.

\section{FERTILIZATION}

Fertilization follows directly upon the division of the generative cell and the maturation of the egg cell. In the summer of 1905 fertilization in $J$. communis occurred on June $\mathrm{I} 7,20$, and $2 \mathrm{I}$. In ovules put up on the same day were found divisions of the central cell to form the egg cell and ventral canal nucleus, undivided generative cells, sperm cells, fertilization, and proembryos. This would indicate that these divisions take place very rapidly. A mass of densely staining, coarse-grained cytoplasm accompanies the sperm nucleus on its entrance into the egg. Whether the other contents of the tube enter the archegonium was not clearly determined; in one preparation there were densely staining bodies in the upper part of the archegonium, which might be the disorganized remains of the 
other nuclei. NoRÉn states that as a rule the two free nuclei do not enter the archegonium. The sperm cell loses its cytoplasm and passes directly to the egg nucleus. When the two nuclei have come in contact, they appear of about the same density and each contains a nucleolus and several secondary nucleoli (fig. 29). The only apparent difference is in size, the sperm nucleus being somewhat smaller. In one instance they were almost equal in size, and a dense mass of cytoplasm almost completely surrounded them.

This densely staining mass is doubtless the cytoplasm of the sperm cell (fig. 30). Sludsky (22) describes the nucleus of the functional sperm cell as escaping from its cytoplasm and fusing with the egg nucleus, while the rest of the sperm cell forms a cap over the fusion nucleus. Whether the two sexual nuclei fuse and form one nucleus could not be determined with absolute certainty. In one preparation a nucleus was present a little below the middle of the archegonium, with a small vacuole above it and one below it. The nucleus is at rest, a chromatic network is present, and a large nucleolus (fig. $3 I$ ). It seems very probable that this is a fusion nucleus on its way to the bottom of the archegonium, as this is not the position which the egg nucleus ordinarily has before fertilization, and no other nucleus was present in this archegonium.

SLUdSky (22) observed a large vacuole in the upper part of the archegonium after fertilization. He thinks this originates by the flowing together of the many small vacuoles, which he believes enter the archegonium from the pollen tube. It seems to me, however, that this vacuole is but the remains of the large vacuole present before fertilization. NoRÉn (I9) finds that the large central vacuole of the egg often disappears before the conjugation of the sexual nuclei.

In one case there occurred what appeared to be the fusion of the ventral canal nucleus with the second sperm nucleus. Two nuclei are present in the chalazal end of this archegonium. These are unquestionably the first two cells of the proembryo. Thus the fusing nuclei in the micropylar end of the archegonium cannot be the egg and the sperm nucleus (fig. 35). LAND (I4) has reported a similar instance in Thuja and considers it a case of the fertilization of both the ventral canal nucleus and of the egg nucleus in the same archegonium. 
I cannot confirm StRASBURger's (24) observation that the fusion nucleus moves to the organic apex of the archegonium before it divides. Fig. 32 shows two nuclei in the resting stage and surrounded with cytoplasm of netlike appearance, about half-way between the middle of the archegonium and its lower extremity. While the cells of the proembryo are undergoing division, the cytoplasm is alveolar and very similar to that in the generative cell just before fertilization, except that the network is slightly finer ( $f g .34$ ).

Following fertilization, the three sporophylls of the pistillate cone fuse over the three ovules and form a berry-like fruit. As a rule the mature fruit contains but one or two seeds, the other ovules or ovule having ceased to grow before reaching maturity.

\section{PHYLOGENY}

From this study of Juniperus, it will be seen that in many respects this genus seems to be of more modern origin than many of the other gymnosperms. The cyclic arrangement of leaves and sporophylls, the absence of prothallial cells in the mature pollen grain, the absence of a ventral canal cell, and the presence of two functional sperm cells over an archegonial complex lead to this conclusion. Jefrerey (IO, II), in his investigations on the woods of the different gymnosperms, says that the wood of Juniperus and other Cupresseae indicates that they belong to a family more modern than the Abieteae. And Thomson (28), as a result of his study of the development of the megaspore coat and of the tapetum, concludes that "the Abieteae are the most ancient group of the Coniferales and the Taxeae the most recent, that the Taxoideae and Podocarpeae are complex, including both ancient and recent forms; and that the Cupresseae occupy an intermediate position in the phylogenetic series."

\section{SUMMARY}

The staminate cones consist of many sporophylls, each bearing microsporangia on the under side near the axis.

The pistillate cones contain three ovules, each subtended by a sporophyll. 
The mature pollen grain contains but one cell, no prothallial cells being present.

The macrospore mother cell first appears in $J$. communis one year after pollination. The first mitosis taking place within it shows clearly the stages characteristic of heterotypic division.

The contents of the pollen grain divide into antheridial cell and tube cell soon after pollination.

In $J$. communis the antheridial cell remains in the pollen grain and does not divide until April of the next spring.

In $J$. virginiana the antheridial cell divides in the early summer of the same year in which pollination takes place, and fertilization occurs in the latter part of June or first of July.

The generative cell and the stalk cell migrate immediately into the tube.

The stalk nucleus passes the generative cell and lies near the tube nucleus.

The generative cell does not divide until after the pollen tube has reached the archegonia and just before fertilization.

Two similar sperm cells are formed, each hemispherical in shape.

The female prothallium develops, as in the other gymnosperms, by free cell formation in a hollow sphere of cytoplasm. After many nuclei are formed, cell walls are laid down between them. These cells grow toward the center, but before they meet, cross-walls are laid down.

The archegonia develop from superficial cells at the micropylar end of the prothallium. They are arranged in a group, and the entire complex is surrounded by a single layer of sheath cells.

During the same day that the generative cell divides, and presumably before its division, the central cell of the archegonium divides.

A ventral canal nucleus is formed and remains throughout its life free in the cytoplasm of the egg, that is, no true ventral canal cell is ever cut off. This nucleus remains at the tip of the egg and, as a rule, soon disintegrates.

After fertilization the first division occurs before the fusion nucleus has passed to the organic apex of the archegonium.

In conclusion I wish to express my sincere gratitude to Professor 
Margaret C. Ferguson, under whose direction the present investigation was carried on, and to whom I am greatly indebted for suggestions and encouragement.

WellesLey College

\section{LITERATURE CITED}

I. BelajefF, W., Zur Lehre von dem Pollenschläuche der Gymnospermen. Ber. Deutsch. Bot. Gesells. 9:280-287. I89I.

2. - Zur Lehre von dem Pollenschläuche der Gymnospermen. Ber. Deutsch. Bot. Gesells. II: I96-20I. I893.

3. Chamberlain, C. J., Development of Juniperus. Bot. Gazette 46:237. I908. (Abstract of 20 infra.)

4. Cienkowsky, Zur Befruchtung des Juniperus communis. Bull. Soc. Imp. Nat. Moscou. I853.

5. Coker, W. C., On the gametophytes and embryo of Taxodium. Bот. GazetTe 36: I-27, II4-I33. I903.

6. - - On the spores of certain Coniferae. Вот. Gazetre 38:206-2I3. I904.

7. Ferguson, M. C., Contributions to the knowledge of the life history of Pinus. Proc. Wash. Acad. Sci. 6: I-202. I904.

8. Hofmeister, W., On the germination, development, and fructification of the higher Cryptogamia, and on the fructification of the Coniferae; English trans. by F. Currey, London, I-49I. I862.

9. Ikeno, S., Untersuchungen über die Entwickelung der Geschlechtsorgane und den Vorgang der Befruchtung bei Cycas revoluta. Jahrb. Wiss. Bot. 32:557-602. 1898 .

Io. Jefreey, E. C., The comparative anatomy and phylogeny of the Coniferales. Part I. The genus Sequoia. Mem. Boston Soc. Nat. Hist. 5:44I-459. I903.

II. - - Idem. Part II. The Abietineae. 6: I-37. I905.

I2. Juel, H. O., Ueber den Pollenschlauch von Cupressus. Flora 93:56-62. I904.

I3. Kubart, B., Die weibliche Blüte von Juniperus communis L. Sitzb. Kais. Akad. Wiss. Wien, Math.-Nat. Kl. II5: I-29. 1905.

I4. LAND, W. J. G., A morphological study of Thuja. Bot. Gazette 36:249259. 1902 .

I5. Lawson, A. A., The gametophytes, archegonia, fertilization and embryo of Sequoia sempervirens. Annals of Botany 18: I-28. I904.

I6. - - The gametophytes, fertilization and embryo of Cryptomeria japonica. Annals of Botany I8:4I $7^{-4} 44$. I904.

I7. - The gametophytes and embryo of the Cupressineae with special reference to Libocedrus decurrens. Annals of Botany 21:28I-30I. I907.

I8. LOPRIORE, G., Ueber die Vielkörnigkeit der Pollenkörner von Araucaria Bidwillii Hook. Vorläufige Mitteilung. Ber. Deutsch. Bot. Gesells. 23:335-346. I905. 
I9. Norén, C. O., Ueber die Befruchtung bei Juniperus communis. Arkiv Bot. 3: I-II (No. II). I904.

20. —, Zur Entwicklungsgeschichte des Juniperus communis. Uppsala Universitets Arsskrift I-64. I907.

2 I. Renner, O., Ueber Zwitterblüten bei Juniperus communis. Flora 93:297300. I904.

22. Sludsky, Ueber die Entwicklungsgeschichte des Juniperus communis. Ber. Deutsch. Bot. Gesells. 23:335-346. I905.

23. Sokolowa, C., Naissance de l'endosperme dans le sac embryonnaire de quelques gymnospermes. Bull. Soc. Imp. Nat. Moscou. I880.

24. Strasburger, E., Die Befruchtung bei den Coniferen. pp. 22 . Jena. I869.

25. ——, Die Coniferen und die Gnetaceen. pp. 442. Jena. I872.

26. - Die Angiospermen und die Gymnospermen. pp. I73. Jena. I879.

27. — Ueber das Verhalten des Pollens und die Befruchtungsvorgänge bei den Gymnospermen. Hist. Beitr. 4: I-I56. I892.

28. Thomson, R. B. The megaspore membrane of the gymnosperms. Univ. Toronto Biol. Series 4: I-54. I905.

29. Webber, H. J., Spermatogenesis and fecundation of Zamia. U. S. Dept. Agric., Bur. Pl. Indus. Bull. I I : I-86. I90 .

\section{EXPLANATION OF PLATES I-IV}

The figures were drawn with the aid of an Abbé camera lucida. The degree of magnification is indicated in the description of each figure. The following abbreviations are used in connection with the figures. Antheridial cell, $a$; archegonium, arch; archesporial tissue, a.t; central cell, $c$; central nucleus, $c . n$; cytoplasmic condensation, $c . c$; egg nucleus, e. $n$; generative cell, $g$; inner wall, $i . w$; integument, $i$; micropyle, M; microspore mother cell, Mi. m. c; microsporangium, $M g$; microsporophyll, $M p$; nucellar cap, $n$. $c$; neck cells, $n k$; nucellus, $n u c$; outer wall, o. w; pollen chamber, p. $c$; prothallium, pro; protein vacuole, $p . v$; starch, $s$; secondary nucleoli, s. $n u$; sperm cell, sp; sperm nucleus, s. $n$; spongy tissue, s. $t$; sheath cell, sh. $c$; stalk cell, st. $c$; stalk nucleus, st. $n$; tapetum, $t$; tube cell, $t . c$; tube nucleus, $t . n$; ventral canal nucleus, v. $c . n$.

PLATE I

FIG. I.-Longitudinal section of staminate cone of $J$. communis; April 25, I905. $\times 62$.

FIG. 2.-Microsporangium of $J$. communis, showing microspore mother cells, tapetum, and wall; May $\mathrm{x}$, I905. $\times 382$.

FIG. 3.-Mature microspore of $J$. communis, just before pollination, $\times 1850$.

FIG. 4.-Pollen grain of $J$. communis, from the nucellus of an ovule, in prophase of first division; May 26, I905. X I $850 .^{\circ}$

FIG. 5.-A two-celled pollen grain of $J$. virginiana, two weeks after pollination. $\times 1850$.

FIG. 6.-Nucellar cap of $J$. virginiana, showing disintegration of cells beneath the pollen grain. $\times$ iा6. 
Fig. 7.- Early stage in the piercing of the nucellar cap by the pollen tube of $J$. communis; June 3 , I905. $\times 884$.

FIG. 8.- Young pollen tube of $J$. virginiana; June I, I905. $\times 382$.

FIG. 9.-Upper part of the pollen tube of $J$. communis, showing the stalk cell and the generative cell; May 8, 1905. $\times 1850$.

FIG. Io.-Pollen tube of $J$. communis, showing the tearing-away of the cytoplasm of the stalk cell from the wall of the old pollen grain; May Io, I905. $\times 884$.

FIG. II.-Portion of pollen tube of $J$. virginiana, midway through the nucellus, showing the generative cell with the tube and the stalk nuclei just beneath it. $\times 1850$.

PLATE II

FIG. I2.--Lower portion of an older pollen tube of $J$. virginiana, showing the two free nuclei below the generative cell. $\times$ I850.

FIG. I3.-The generative cell of $J$. communis, just before division; June 9, I903. $\times 884$.

Frg. I4.-Longitudinal section of ovule of $J$. communis, showing nucellus and integument; spongy tissue not yet clearly differentiated; May ı9, г905. X г16.

FIG. I5.-Longitudinal section of ovule of $J$. virginiana, showing an occasional method of closing the micropyle. X $\mathrm{x}$ i6.

FIG. I6.--Longitudinal section of ovule of $J$. communis in winter condition, showing usual method of closing of micropyle; March 28, I905. X II6.

FIG. I7.-Macrospore mother cell of $J$. communis; April I4, I905. $\times 704$.

FIG. I8.-Macrospore mother cell of $J$. communis, in prophase of division with spongy tissue around it; April I7, I905. $\times 704$.

FIGS. I9-2I.-Different stages in the division of the macrospore mother cell of $J$. communis; April I7, I905. $\times 1850$.

FIG. 22.-Two-celled embryo sac of $J$. communis; May I, I905. $\times 704$.

$$
\text { PLATE III }
$$

FIG. 23.-Longitudinal section of the nucellus of $J$. communis, showing the hollow prothallium almost a year after pollination; May 5, I905. XI88.

FIG. 24.-Prothallium of $J$. communis, almost closed at the center, with archegonia at the micropylar end; May 30, 1903. $\times 62$.

FIG. 25.--Stages in the development of archegonia in the same archegonial complex of $J$. communis; May 30, I903. $\times 704$.

FIG. 26.-Longitudinal section of archegonium of $J$. communis, at the time of the division of the central cell; nucleus in prophase of division; large central vacuole and prominent radiations; June 20 , I905. $\times 704$.

FIG. 27.-Longitudinal section of an archegonial complex of $J$. communis, with the tip of the pollen tube above it; June 20, I905. $\times 382$.

$$
\text { PLATE IV }
$$

FIG. 28.-Upper portion of archegonium of $J$. communis just before fertilization; June 20, I905. X $\times$ ז0I6.

FIGS. 29, 30.-Conjugation of sexual nuclei of $J$. communis, showing sheath of denser cytoplasm; June 20, I905. XI850, 884 . 
FIG. 3I.-Fusion nucleus of $J$. communis between two vacuoles; June 20, I905. $\times 884$.

FIG. 32.-Two-celled proembryo of $J$. communis, surrounded by mass of nutritive substance; June 9, I903. $\times 382$.

FIG. 33.-Second division after fertilization at base of archegonium of $J$. communis; June I7, I905. $\times 884$.

FIG. 34.-Divisions to form the eight-celled proembryo of $J$. communis; June 20, I905. $\times 884$.

FIG. 35.-Probable fertilization of the ventral canal nucleus of $J$. communis; June I7, I905. $\times$ I60.

FIG. 36.-Abnormal position of an archegonium of $J$. communis, just outside the complex; June 20, r905. $\times 382$. 

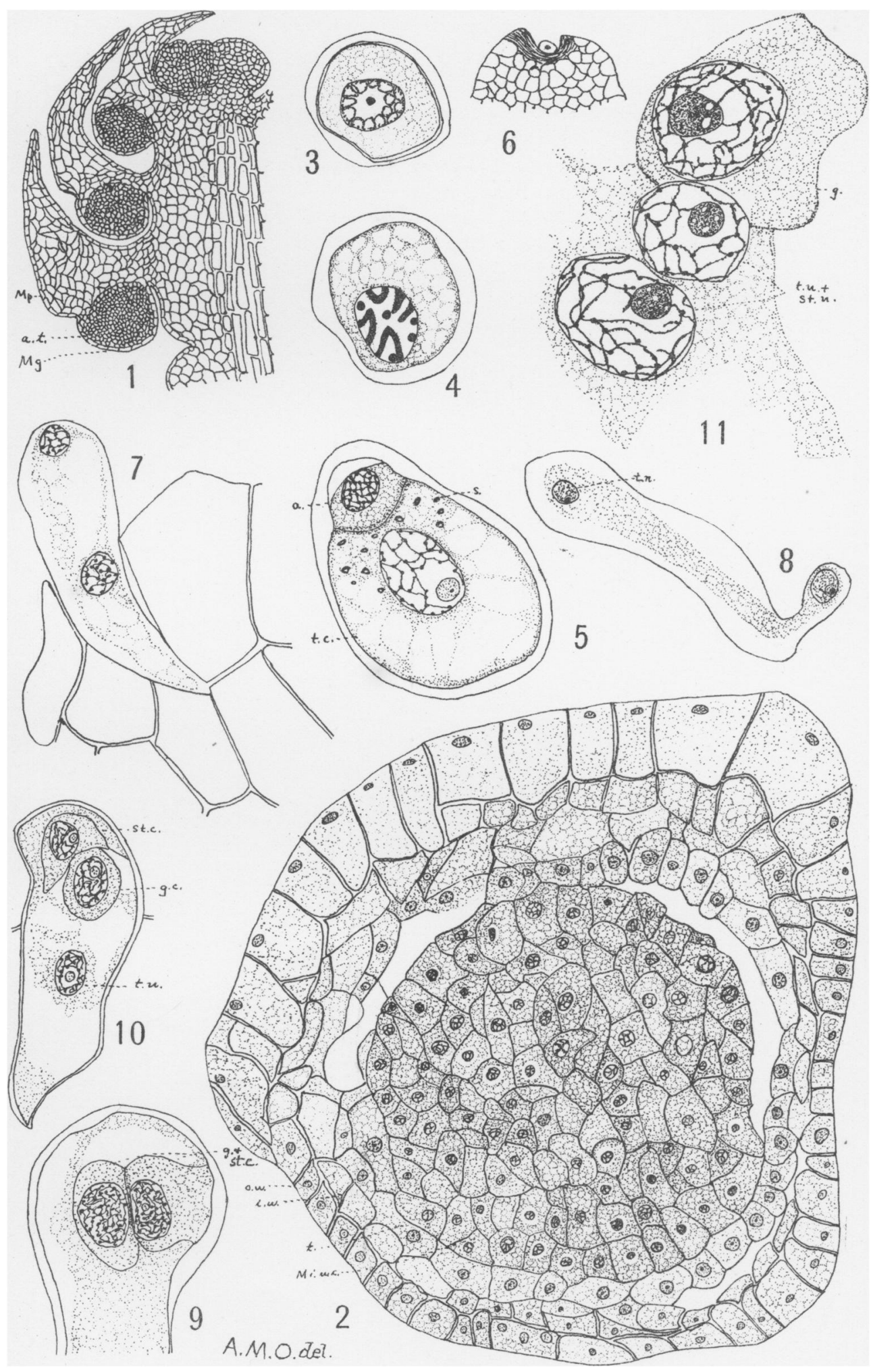

OTTLEY OI JINIPERIS

This content downloaded from 129.219.247.033 on August 27, 2016 16:19:30 PM

All use subject to University of Chicago Press Terms and Conditions (http://www.journals.uchicago.edu/t-and-c). 


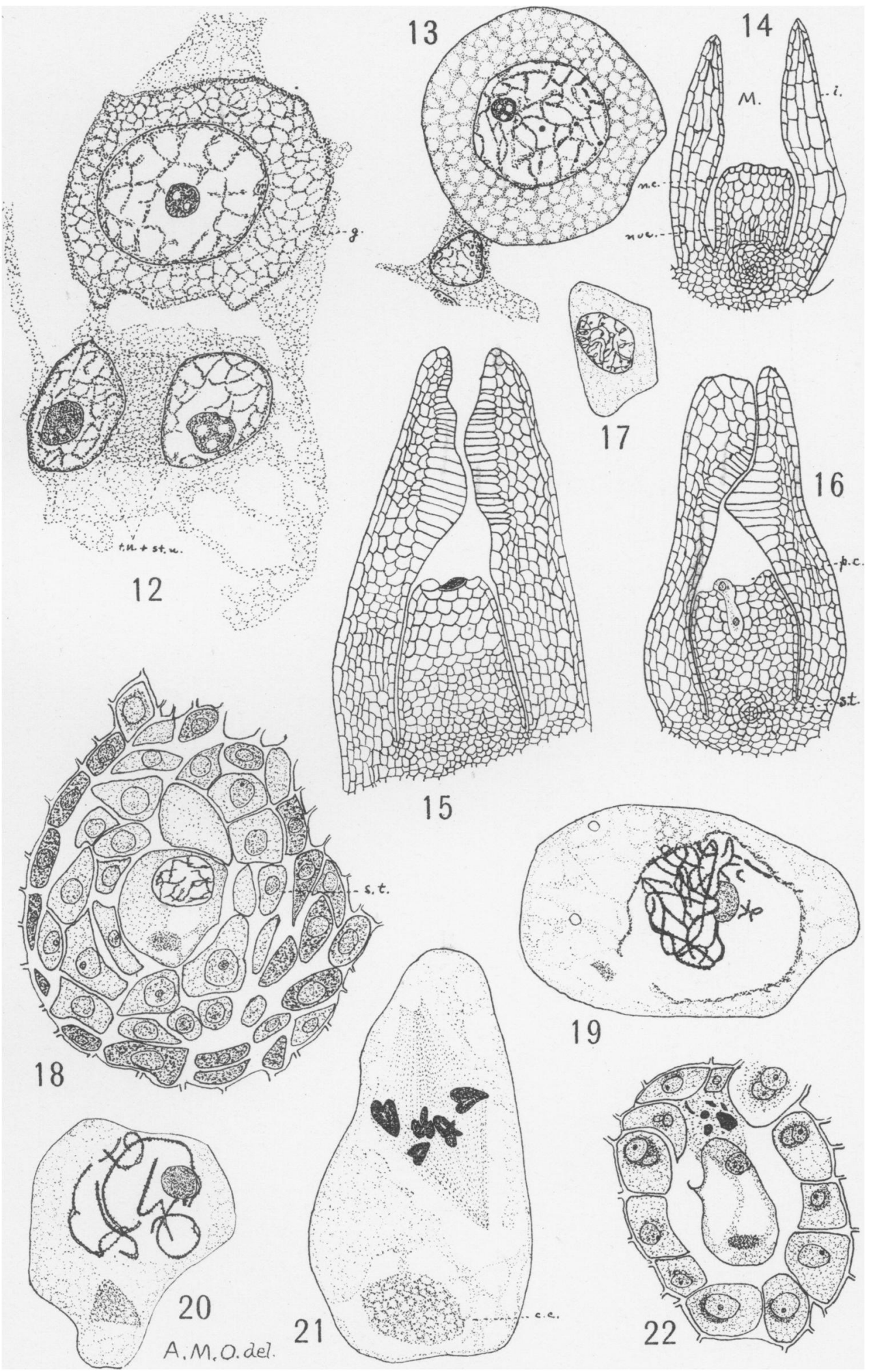

This content downloaded from 129.219.24F.033 on August 27, 2016 16:19:30 PM All use subject to University of Chicago Press Terms and Conditions (http://www.journals.uchicago.edu/t-and-c). 

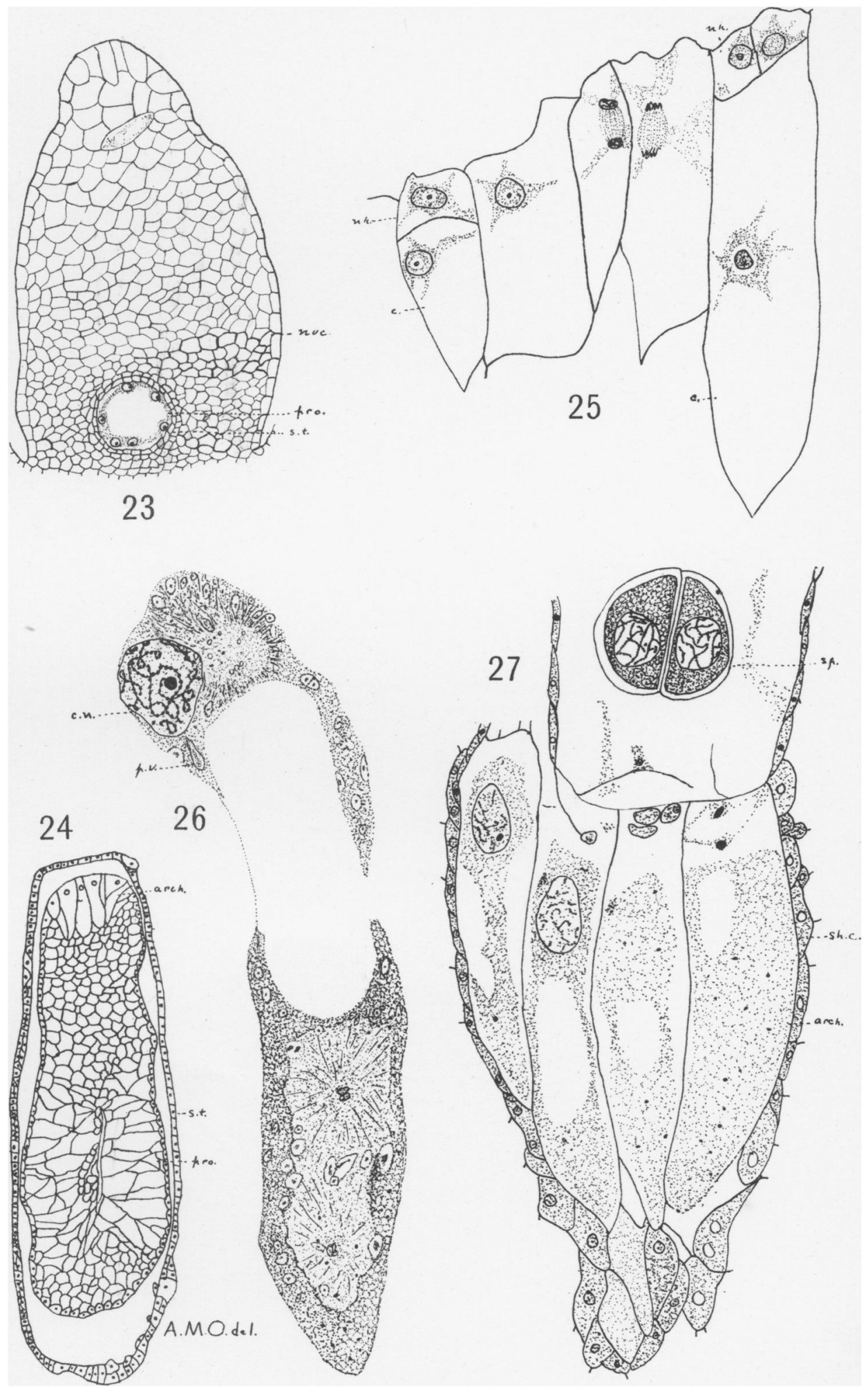

\section{OTTLEY OO JUNIPERUS}

This content downloaded from 129.219.247.033 on August 27, 2016 16:19:30 PM

All use subject to University of Chicago Press Terms and Conditions (http://www.journals.uchicago.edu/t-and-c). 


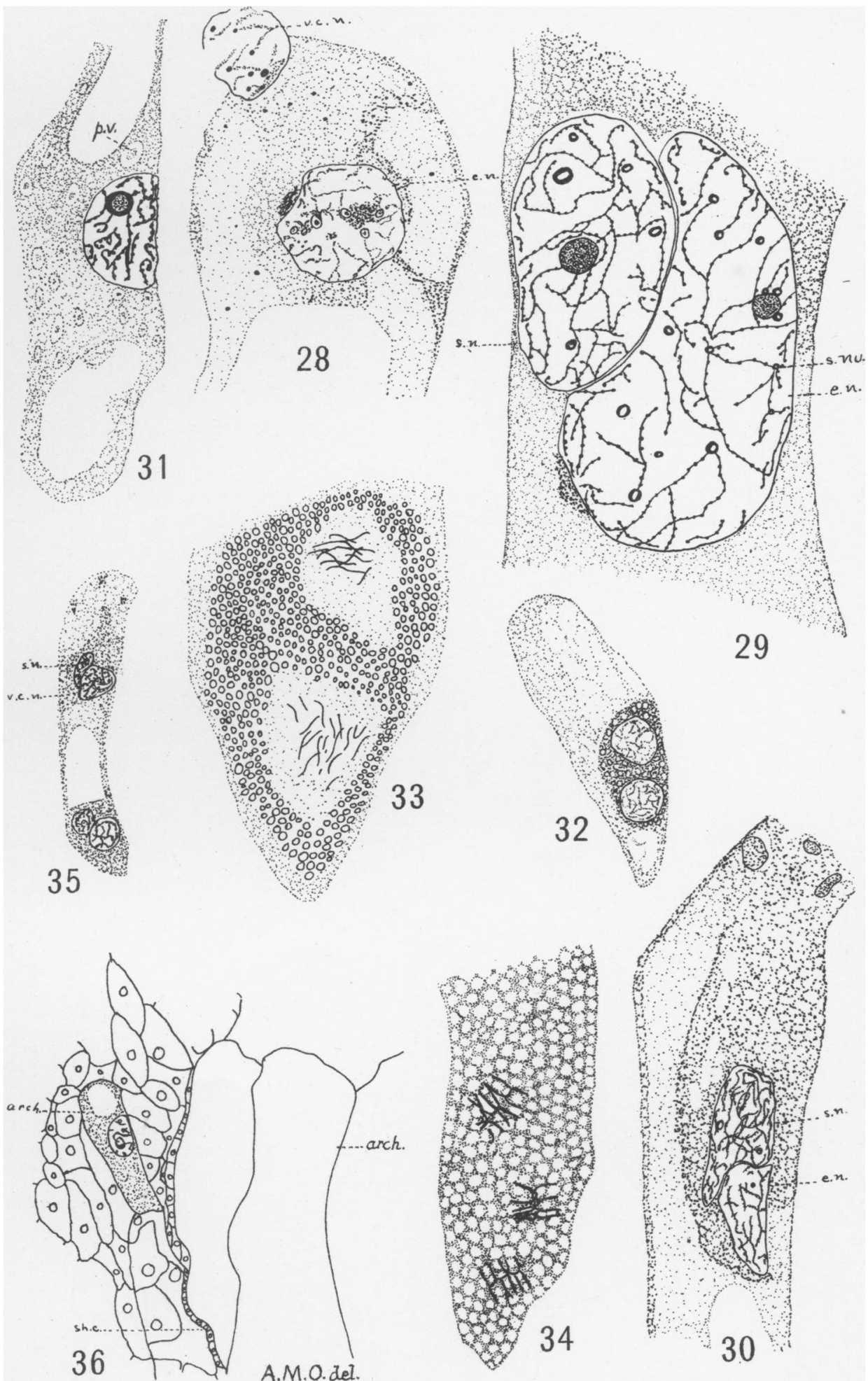

OTTLEY ON JUNIPERUS

This content downloaded from 129.219.247.033 on August 27, 2016 16:19:30 PM

All use subject to University of Chicago Press Terms and Conditions (http://www.journals.uchicago.edu/t-and-c). 